\title{
Amiloride prevents amphotericin B related hypokalaemia in neutropenic patients
}

\author{
S R SMITH, * M J GALLOWAY, $\dagger$ J T REILLY, ${ }^{*}$ J M DAVIES* \\ From the *University Department of Haematology, Royal Liverpool Hospital, Liverpool, and the †Department \\ of Haematology, Walton Hospital, Liverpool
}

SUMMARY Twenty neutropenic patients with various haematological disorders were randomised prospectively to receive either intravenous amphotericin B alone or amphotericin B and oral amiloride $5 \mathrm{mg}$ twice a day for treatment of confirmed or suspected fungal infection. Patients receiving amiloride had a significantly higher plasma potassium $(\mathrm{p}<0.01)$, a significantly lower urinary potassium loss $(\mathrm{p}<0.01)$, and required significantly less potassium chloride supplementation to maintain their plasma potassium within the normal range $(\mathrm{p}<0.001)$. Amiloride was well tolerated, had no clinically important side effects, and provided effective control of plasma potassium in patients treated with amphotericin B.

Invasive fungal infections are an important cause of morbidity and mortality in neutropenic patients. Amphotericin B is the most effective drug currently available for the management of systemic fungal infections in such patients, but nephrotoxicity is a major limiting factor in its use.' The nephrotoxic effects of amphotericin $B$ are due to combined actions on both the glomeruli and renal tubules. In particular, selective distal tubular epithelial toxicity seems to be, at least in part, responsible for the profound potassium wasting which is a major clinical side effect of treatment with amphotericin $\mathrm{B}^{2-4}$

Recent studies have also shown that amphotericin $B$ also affects sodium flux in both the distal and transverse human colon, suggesting a further site of changed sodium/potassium exchange in patients treated with this agent. ${ }^{5}$

The management of potassium wasting induced by amphotericin B may be difficult, and even large intravenous doses of potassium chloride may not be fully effective in correcting the hypokalaemia. As a consequence, clinical problems, especially muscle weakness and cardiac arrhythmias, are seen in a proportion of patients.

Amiloride, a pyrazine derivative, is a potassium sparing diuretic widely used in clinical practice. It increases urinary excretion of sodium and bicarbonate while decreasing urinary potassium excretion by the distal convoluted tubule. ${ }^{6}$ Amiloride also has actions outside the kidney and inhibits sodium absorption

Accepted for publication 16 December 1987 from the distal colon. Furthermore, the action of amiloride on this site potentially antagonises the effects of amphotericin B. ${ }^{5}$

The aim of this study was to determine whether amiloride could prevent the hypokalaemia associated with treatment with amphotericin B.

\section{Patients and methods}

Twenty consecutive neutropenic (absolute neutrophil count $\left.<0.5 \times 10^{9} / 1\right)$ patients with various haematological disorders were entered into the study over six months. The study was approved by the appropriate local ethical committees and all patients gave informed written consent. The indications for amphotericin B treatment were either evidence of invasive fungal infection diagnosed by biopsy and culture, or fever unresponsive to five days of broad spectrum antibiotics in the presence of continuing neutropenia. ${ }^{7}$

On entry into the study patients were randomised to receive either amphotericin B alone intravenously or amphotericin B intravenously with oral amiloride 5 $\mathrm{mg}$ twice a day. Both groups received identical combinations of broad spectrum antibiotics before entry into the study, and there was no difference in aminoglycoside administration between the two groups. Broad spectrum antibiotics were continued throughout amphotericin B treatment in all but two patients. All patients received a standard hospital diet containing $40 \mathrm{mmol}$ potassium/day except one patient (case 9) in the group taking amphotericin alone who required parenteral feeding. 
Patients with an initial serum creatinine concentration of $>200 \mu \mathrm{mol} / 1$ and those taking cyclosporin A for graft versus host disease after allogeneic bone marrow transplantation were excluded from entry into the study.

DRUG ADMINISTRATION

Amphotericin B was administered by slow intravenous injection in 5\% dextrose over six hours. On day 1 a $1 \mathrm{mg}$ test dose was given intravenously over two hours followed by $4 \mathrm{mg}$ intravenously over the next four hours. On day 2 the dose of amphotericin $B$ given was increased to $0.25 \mathrm{mg} / \mathrm{kg}$, again given over six hours. On day 3 and thereafter the dose was maintained at $0.5 \mathrm{mg} / \mathrm{kg}$ body weight a day. Amiloride $(5 \mathrm{mg})$ was administered orally at $9.00 \mathrm{am}$, one hour before amphotericin B administration and at $9.00 \mathrm{pm}$ five hours after amphotericin B administration had been completed.

\section{ELECTROLYTE MEASUREMENTS}

Plasma potassium, sodium, and creatinine were measured daily on a sequential multiple analysis/computer (Technicon). Daily 24 hour urinary potassium was measured using a flame photometric method. (Instrumentation laboratories 143). Serum magnesium was measured using an atomic absorption spectrophotometer.

Plasma potassium, total oral, and intravenous potassium supplementation per day and 24 hour urinary potassium losses were measured for patients in both groups.

\section{POTASSIUM SUPPLEMENTATION}

Group taking amphotericin alone

Oral potassium chloride was given if plasma potassium fell below $3.5 \mathrm{mmol} / \mathrm{l}$. Initially $48 \mathrm{mmol}$ of oral potassium chloride were given every 24 hours and this was increased to $96 \mathrm{mmol}$ after 24 hours if plasma potassium remained below $3.5 \mathrm{mmol} / \mathrm{l}$.

\section{Group taking amphotericin and amiloride}

Potassium chloride ( $48 \mathrm{mmol}$ ) was given at the start of amphotericin treatment if the plasma potassium was 3 $\mathrm{mmol} / \mathrm{l}$ or lower. During treatment with amphotericin, oral supplements were given to maintain the plasma potassium at $3.5 \mathrm{mmol} / \mathrm{l}$, or if the observed trend in plasma potassium predicted a fall below $3.5 \mathrm{mmol} / 1$.

If oral supplementation was inadequate or poorly tolerated in either group then intravenous potassium chloride was given and requirements titrated to maintain a plasma potassium above $3.5 \mathrm{mmol} / 1$.

Amphotericin B treatment was discontinued when a full course of treatment had been completed for documented fungal infection or when neutrophil recovery and defervescence of fever had occurred in those patients treated on an empirical basis.

Results were analysed statistically using the MannWitney U test.

\section{Results}

The two patient groups studied were broadly similar in terms of age, underlying haematological diagnosis, and duration of amphotericin B treatment (tables 1 and 2).

Plasma potassium, urinary potassium losses, and daily potassium requirements for the patients receiving amphotericin $B$ alone and patients receiving amphotericin B with amiloride are shown in tables 1 and 2, respectively. Plasma potassium was significantly higher in the group receiving amiloride. $(\mathrm{p}<0.01)$, while potassium supplementation was significantly higher in the group receiving amphotericin alone $(\mathrm{p}<0.001)$.

Table 1 Patient characteristics of group taking amphotericin alone

\begin{tabular}{|c|c|c|c|c|c|c|c|c|}
\hline \multirow[b]{2}{*}{$\begin{array}{l}\text { Case } \\
\text { No }\end{array}$} & \multirow[b]{2}{*}{$\begin{array}{l}\text { Age } \\
\text { (years) }\end{array}$} & \multirow[b]{2}{*}{ Diagnosis } & \multicolumn{6}{|c|}{ Plasma potassium ( $\mathrm{mmol} / \mathrm{l})$} \\
\hline & & & $\begin{array}{l}\text { Days on } \\
\text { amphotericin B } \\
\text { treatment at } 0 \cdot 5 \\
\text { mg } / \mathrm{kg} / \text { day }\end{array}$ & $\begin{array}{l}\text { Range of } \\
\text { plasma }\end{array}$ & $\begin{array}{l}\text { Mean } \\
\text { plasma }\end{array}$ & $\begin{array}{l}\text { Range of daily } \\
\text { supplements/day }\end{array}$ & $\begin{array}{l}\text { Mean daily } \\
\text { supplements/day }\end{array}$ & $\begin{array}{l}\text { Mean } 24 \text { hour } \\
\text { urinary } \\
\text { excretion/day }\end{array}$ \\
\hline $\begin{array}{l}1 \\
2 \\
3 \\
4 \\
5 \\
6 \\
7 \\
8 \\
9 \\
10\end{array}$ & $\begin{array}{l}39 \\
60 \\
61 \\
56 \\
49 \\
43 \\
47 \\
56 \\
74 \\
18\end{array}$ & $\begin{array}{l}\text { ALL } \\
\text { AML } \\
\text { AML } \\
\text { AML } \\
\text { AML } \\
\text { AML } \\
\text { AML } \\
\text { AML } \\
\text { HD } \\
\text { ALL }\end{array}$ & $\begin{array}{r}13 \\
12 \\
11 \\
8 \\
14 \\
11 \\
7 \\
5 \\
4 \\
15\end{array}$ & 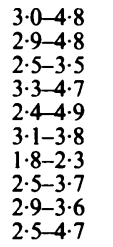 & $\begin{array}{l}3 \cdot 70 \\
3 \cdot 58 \\
3 \cdot 09 \\
3 \cdot 98 \\
3 \cdot 57 \\
3 \cdot 40 \\
2 \cdot 12 \\
3 \cdot 14 \\
3 \cdot 32 \\
3 \cdot 58\end{array}$ & $\begin{array}{r}0-124 \\
32-153 \\
217-358 \\
48-96 \\
60-180 \\
88-144 \\
80-360 \\
40-240 \\
96-150 \\
100-280\end{array}$ & $\begin{array}{r}71 \\
94 \\
243 \\
90 \\
106 \\
113 \\
194 \\
113 \\
109 \\
169\end{array}$ & $\begin{array}{r}54 \cdot 1 \\
69 \cdot 3 \\
111 \cdot 0 \\
106 \cdot 9 \\
90 \cdot 8 \\
137 \cdot 2 \\
56 \cdot 4 \\
92 \cdot 0 \\
120 \cdot 8\end{array}$ \\
\hline
\end{tabular}

ALL = Acute lymphoid leukaemia AML = Acute myeloid leukaemia $\mathrm{HD}=$ Hodgkin's disease 
Table 2 Patient characteristics of group taking amphotericin and amiloride

\begin{tabular}{|c|c|c|c|c|c|c|c|c|}
\hline \multirow[b]{2}{*}{$\begin{array}{l}\text { Case } \\
\text { No }\end{array}$} & \multirow[b]{2}{*}{$\begin{array}{l}\text { Age } \\
\text { (years) }\end{array}$} & \multirow[b]{2}{*}{ Diagnosis } & \multicolumn{6}{|c|}{ Plasma potassium ( mmol/l) } \\
\hline & & & $\begin{array}{l}\text { Days on } \\
\text { amphotericin B } \\
\text { treatment at } 0 \cdot 5 \\
\mathrm{mg} / \mathrm{kg} / \text { day }\end{array}$ & $\begin{array}{l}\text { Range of } \\
\text { plasma }\end{array}$ & $\begin{array}{l}\text { Mean } \\
\text { plasma }\end{array}$ & $\begin{array}{l}\text { Range of daily } \\
\text { supplements/day }\end{array}$ & $\begin{array}{l}\text { Mean daily } \\
\text { supplements/day }\end{array}$ & $\begin{array}{l}\text { Mean } 24 \text { hour } \\
\text { urinary } \\
\text { excretion/day }\end{array}$ \\
\hline $\begin{array}{l}1 \\
2 \\
3 \\
4 \\
5 \\
6 \\
7 \\
8 \\
9 \\
10\end{array}$ & $\begin{array}{l}19 \\
62 \\
66 \\
18 \\
55 \\
61 \\
65 \\
35 \\
57 \\
56\end{array}$ & $\begin{array}{l}\text { ALL } \\
\text { AML } \\
\text { AML } \\
\text { ALL } \\
\text { MDS } \\
\text { CLL } \\
\text { AML } \\
\text { AML } \\
\text { MM } \\
\text { AML }\end{array}$ & $\begin{array}{r}8 \\
4 \\
3 \\
7 \\
21 \\
3 \\
8 \\
9 \\
5 \\
11\end{array}$ & $\begin{array}{l}1 \cdot 9-3 \cdot 8 \\
3 \cdot 1-4 \cdot 6 \\
2 \cdot 8-4 \cdot 6 \\
4 \cdot 0-5 \cdot 1 \\
3 \cdot 1-5 \cdot 3 \\
3 \cdot 6-4 \cdot 8 \\
3 \cdot 9-5 \cdot 2 \\
3 \cdot 2-4 \cdot 3 \\
3 \cdot 5-4 \cdot 4 \\
2 \cdot 9-3 \cdot 8\end{array}$ & $\begin{array}{l}2 \cdot 78 \\
3 \cdot 80 \\
3 \cdot 73 \\
4 \cdot 62 \\
4 \cdot 25 \\
4 \cdot 20 \\
4 \cdot 47 \\
3 \cdot 77 \\
3 \cdot 80 \\
3.43\end{array}$ & $\begin{array}{l}48-96 \\
0 \\
16-48 \\
0 \\
0 \\
0-32 \\
0 \\
16-64 \\
0-52 \\
0-48\end{array}$ & $\begin{array}{l}88 \\
0 \\
26 \cdot 6 \\
0 \\
0 \\
10 \cdot 6 \\
0 \\
41 \cdot 7 \\
18 \cdot 4 \\
32\end{array}$ & $\begin{array}{c}64 \cdot 0 \\
38 \cdot 3 \\
42 \cdot 0 \\
100 \cdot 3 \\
17 \cdot 1 \\
38 \cdot 3 \\
49 \cdot 2 \\
65 \cdot 1 \\
48 \cdot 0 \\
30 \cdot 0\end{array}$ \\
\hline
\end{tabular}

$\overline{\mathrm{ALL}}=$ Acute lymphoid leukaemia

AML = Acute myeloid leukaemia

MDS $=$ Myelodysplastic syndrome

CLL = Chronic lymphatic leukaemia

MM = Multiple myeloma

Four patients receiving amiloride required no potassium supplementation during amphotericin B treatment and of the six remaining patients, only two required intravenous potassium supplementation. In contrast, all patients receiving amphotericin B alone required potassium supplementation with nine patients requiring intravenous potassium. Urinary losses of potassium were significantly higher in patients treated with amphotericin B alone when compared with patients receiving additional amiloride $(p<0.01)$. Observed ranges in plasma potassium, 24 hour urinary potassium losses, and daily potassium



Figure Median and range of plasma potassium, 24 hour urinary potassium excretion, and daily potassium supplements for both groups. supplementation for each group are summarised in the figure.

Daily potassium balance was calculated for the two groups from measurements of daily potassium intake and daily urinary potassium losses. Patients receiving amphotericin alone showed an apparent mean daily positive potassium balance of $79.3 \mathrm{mmol}$ (range +23 mmol to $+172 \mathrm{mmol}$ ) while the group receiving additional amiloride showed a paradoxically smaller daily gain of $13.6 \mathrm{mmol}$ (range $-60 \mathrm{mmol}$ to +66 mmol).

\section{SIDE EFFECTS}

There was no clinically important side effects in the group receiving additional amiloride. Four patients developed clinically unimportant hyponatraemia with the lowest recorded plasma sodium in the range 128$125 \mathrm{mmol} / 1$. Three patients in each group had a minor rise in serum creatinine which did not lead to suspension of treatment. Hypomagnesaemia requiring correction with intravenous magnesium developed in two patients receiving amphotericin $B$ alone and in one patient receiving amphotericin $B$ and amiloride.

\section{Discussion}

Severe hypokalaemia is the most serious side effect of amphotericin B treatment. ${ }^{3}$ The correction of hypokalaemia is difficult and may require up to 300 mmol of potassium chloride replacement a day. Oral potassium chloride supplementation in high doses is often poorly tolerated in neutropenic patients due to associated mucositis, and large intravenous doses of potassium chloride requiring careful monitoring are therefore necessary. An agent that safely decreases potassium requirements in this group of patients would thus be clinically useful. This study has shown 
that amiloride significantly reduces the potassium supplementation required in patients receiving short or prolonged periods of treatment with amphotericin B.

Amiloride seems to act on transport proteins affecting the active movement of ions across cell membranes. The potassium sparing effect of amiloride on renal excretion is thought to be due to blockage of sodium reabsorption in the distal renal tubule rather than to a direct effect on potassium secretion. ${ }^{6}$ Although not specifically addressed in the present study, this distal tubular effect is probably responsible for the reduction by amiloride of urinary potassium losses in subjects treated with amphotericin B.

The well recognised renal action of amiloride does not, however, provide a complete explanation of our data. In particular, patients receiving amphotericin B alone seem to be in gross positive potassium balance, using only urinary losses to calculate daily potassium balance. Potassium retention at this level seems unlikely in the face of the low plasma potassium concentrations observed. A more likely explanation is that potassium loss from the gastrointestinal tract in neutropenic patients is significant even in the absence of gastrointestinal symptoms. In support of this contention is the recent demonstration that amphotericin B affects ion exchange in the colon in man and that this action is potentially antagonised by amiloride. We are currently investigating the effects of amphotericin B and amiloride on gastrointestinal potassium excretion in both neutropenic patients and in a non-neutropenic control group.

The predicted effects of amiloride on plasma sodium were, mild and did not result in clinically important hyponatraemia. Renal magnesium wasting also occurs in patients treated with amphotericin $B$ and the associated clinical problems are well recognised. ${ }^{89}$ Amiloride has been shown to decrease renal magnesium excretion in studies on animals, ${ }^{10}$ and our preliminary data suggest that amiloride may also reduce the urinary magnesium losses seen with treatment amphotericin B in man.

Amiloride was well tolerated by all patients and produced no clinically important side effects. Oral amiloride therefore provides a safe alternative to high dose intravenous potassium replacement in patients undergoing treatment with amphotericin $\mathbf{B}$.

We thank Drs P Stevenson and J Martindale for permission to study patients under their care, and Dr W H Taylor for his helpful advice.

We are grateful for the secretarial assistance of Mrs H R Gawne.

\section{References}

1 Hawkins C, Armstrong D. Fungal infections in the immunocompromised host. Clin Haematol 1984;13:599-630.

2 Patterson RM, Ackerman GL. Renal tubular acidosis due to Amphotericin B nephrotoxicity. Arch Intern Med 1971;127: $241-4$.

3 Douglas JB, Healy JK. Nephrotoxic effects of amphotericin B including renal tubular acidosis. Am J Med 1969;46:154-62.

4 McCurdy NK, Myron F, Elkington JR. Renal tubular acidosis due to Amphotericin B. N Engl J Med 1968;278:124-31.

5 Sellin JH, De Soigne R. Ion transport in human colon in vitro. Gastroenterology 1987;93:441-8.

6 Snoble JK, Varghese L, Sweny P, et al. Renal physiology revisited. Amiloride. Lancet 1986;11:326-8.

7 Pizzo PA, Robichaud KJ, Gill FA, et al. Empiric antibiotic and antifungal therapy for cancer patients with prolonged fever and granulocytopaenia. Am J Med 1982;72:101-11.

8 Barton CA, Pahl H, Vaziri KD, et al. Renal magnesium wasting associated with Amphotericin B therapy. Am J Med 1984; 77:471-544.

9 Davies SV, Murray JA, Amphotericin B, aminoglycoside, and hypomagnesaemic tetany. Br Med J 1986;292:1395-6.

10 Devane J, Ryan MP. Dose dependent reduction in renal magnesium clearance by amiloride during frusemide-induced diuresis in rats. Br J Pharmacol 1983;80:421-8.

Requests for reprints to: Dr J M Davies, University Department of Haematology, Duncan Building, Royal Liverpool Hospital, Prescot Street, PO Box 147, Liverpool L69 3BX, England. 